\title{
Analisis Dampak Pelaksanaan Webinar Terhadap Literasi Keuangan Pada Peserta Webinar Nasional Investasi Saham
}

\author{
Maha Martabar Mangatas Lumbanraja*, Rahmat Junaidi, Sri Wahyuni Wildah \\ Fakultas Ekonomi dan Bisnis, Manajemen, Universitas Riau, Pekanbaru, Indonesia \\ Email: 1," maha.martabar@lecturer.unri.ac.id, ${ }^{2}$ rahmat.junaidi@lecturer.unri.ac.id, ${ }^{3}$ Sri.wildah@lecturer.unri.ac.id \\ Email Penulis Korespondensi: maha.martabar@lecturer.unri.ac.id \\ Submitted: 19/11/2021; Accepted: 29/11/2021; Published: 30/11/2021
}

\begin{abstract}
Abstrak-Pasar Modal telah dikenal sebagai sebuah alternatif pembiayaan dan juga investasi diberbagai negara dengan hadirnya Bursa Efek, namun temuan awal dari penelitian menunjukkan bahwa pengetahuan atas alternatif pembiayaan dan investasi (yang dikenal sebagai Financial Literacy) pada negara maju dan berkembang masih terlihat perbedaan yang signifikan. Peran Literasi Keuangan dalam menciptakan pertumbuhan ekonomi di suatu bangsa pada saat ini menjadi hal yang dijadikan pengamatan oleh sejumlah akademisi, dimana terlihat dengan jelas bahwa negara dengan tingkat literasi keuangan yang semakin baik akan cenderung lebih berkembang daripada negara dengan tingkat literasi keuangan yang lebih rendah. Tingkat literasi keuangan Indonesia yang masih lebih rendah daripada negara tetangga seperti Australia Malaysia dan Singapura pada tahun 2014 mengindikasikan perlunya sejumlah cara yang harus dilakukan salah satunya melalui peranan Universitas dan badan organisasi dibawahnya untuk melakukan fungsi edukasi tersebut. Penelitian ini dilakukan untuk mengetahui dampak pelaksanaan salah satu webinar yang dilakukan oleh Galeri Investasi Universitas Riau dengan tema Mendapat Sama Berlaba, Hilang Sama Merugi: Ciptakan Generasi Melek Investasi” yang diikuti oleh 340 Orang Peserta. Sampel Penelitian menggunakan pendekatan teknik convinience sampling dan ukuran sampel menggunakan tabel bantu King sehingga diperoleh ukuran sampel sebesar 151 orang. Data dianalisis menggunakan pendektan statistik deskriptif (persentase dan cross tabulation analisis). Hasil penelitian menunjukkan bahwa terjadi peningkatan pemahaman pada Peserta sebagai dampak diadakannya Webinar Nasional Saham tersebut, namun demikian masih juga ditemukan peserta yang belum optimal peningkatan pemahamannya sehingga disarankan untuk diberikan pemahaman lebih lanjut melalui seri webinar saham yang diadakan oleh Galeri Investasi Universitas Riau. Penelitian ini juga memiliki keterbatasan analisis menggunakan teknik Statistik Deskriptif yang tidak dapat digeneralisasi secara langsung pada populasi lain dan hal tesebut diharapkan dapat menjadi dasar untuk peneltiian berikutnya melalui permodelan yang dapat diaplikasikan secara langsung pada populasi lainnya.
\end{abstract}

Kata Kunci: Literasi Keuangan; Webinar Pasar Modal; Galeri Investasi; Edukasi Investasi; Investasi Saham

Abstract-The capital market has been known as an alternative financing and investment in various countries with the presence of the Stock Exchange, but the initial findings from the study show that knowledge of alternative financing and investment (known as Financial Literacy) in developed and developing countries still shows significant differences. The role of Financial Literacy in creating economic growth in a nation is currently being observed by a number of academics, where it is clearly seen that countries with better levels of financial literacy will tend to develop more than countries with lower levels of financial literacy. Indonesia's financial literacy level which is still lower than neighboring countries such as Australia, Malaysia and Singapore in 2014 indicates the need for a number of ways that must be done, one of which is through the role of universities and organizational bodies under them to carry out this educational function. This research was conducted to determine the impact of the implementation of one of the webinars conducted by the Investment Gallery, Riau University with the theme "Getting Profit Equal, Losing Equal Losing: Creating an Investment Literate Generation" which was attended by 340 participants. The research sample used a convenience sampling technique approach and the sample size used King's auxiliary table in order to obtain a sample size of 151 people. Data were analyzed using descriptive statistical approach (percentage and cross tabulation analysis). The results showed that there was an increase in understanding among participants as a result of the holding of the National Stock Webinar, however, there were still participants who did not increase their understanding optimally, so it is advisable to provide further understanding through a series of stock webinar held by the Investment Gallery, Riau University. This study also has limited analysis using Descriptive Statistics techniques which cannot be generalized directly to other populations and it is hoped that this can be the basis for further research through modeling that can be applied directly to other populations.

Keywords: Financial Literacy; Capital Market Webinar; Investment Galery; Investment Education; Stock Investment

\section{PENDAHULUAN}

Literasi Keuangan merupakan sebuah isu yang mengemuka terutama pada saat dimana terjadinya perubahan pola pikir dari masyarakat, khususnya pada masyarakat dengan usia muda, dimana terdapat keinginan untuk dapat menghasilkan karya ataupun pekerjaan yang sifatnya produktif di usia muda dan adanya harapan untuk menikmati hidup lebih nyaman pada umur yang relatif masih muda dengan adanya kebebasan finansial. Hal ini dibuktikan dengan munculnya sejumlah jejak pendapat secara global, salah satunya yang dilakukan oleh (Klapper et al., 2019) yang menunjukkan bahwa secara global, masyarakat dengan usia 15-35 Tahun menjadi kelas masyarakat dengan tingkat literasi paling tinggi yaitu 36\%, yang menunjukkan adanya minat yang tinggi dari kelas usia tersebut untuk lebih paham terhadap literasi keuangan dan diharapkan dapat mendukung pengetahuan terkait dengan pembiayaan maupun investasi untuk masa depannya. Hasil ini dapat dilihat pada Gambar 1 berikut.: 


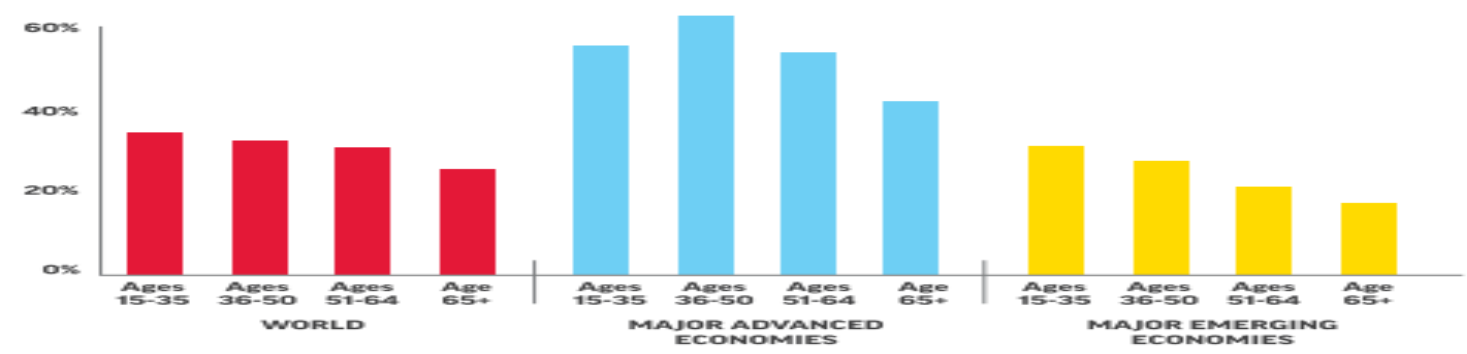

Gambar 1. Gambaran Kemampuan Literasi Keuangan Berdasarkan Usia pada Survei Financial Literacy Arround The World

Sumber: (Klapper et al., 2019, p. 13) (Kozak, 2015)

Dengan melihat hasil pada Gambar 1 tersebut, dapat dilihat fakta yang menunjukkan adanya perbedaan yang signifikan pada kelas usia 15-35 Tahun pada Negara Maju dengan Negara berkembang dalam hal penguasaan literasi digital, dimana pada Negara Maju 56\% telah memiliki kemampuan literasi keuangan yang tinggi, sedangkan pada Negara Berkembang hanya 30\% dari total masyarakat mudanya yang memiliki penguasan terhadap literasi keuangan. Perbedaan pengetahuan tersebut ditenggarai oleh penelitian tersebut menjadi sebab adanya perbedaan pada pemahaman masyarakatnya terhadap pentingnya Literasi Keuangan, dan juga berdampak pada minimnya alternatif yang dimiliki oleh masyarakat khususnya pada masyarakat dengan usia muda dalam utamanya dalam pembiayaan maupun investasi.

Di lain pihak, fakta berseberangan ditunjukkan oleh hasil penelitian yang dilakukan oleh badan lain yaitu OECD International Network on Financial Education (OECD/INFE) yang dipublikasikan dalam (OECD, 2020), yang menunjukkan bahwa walaupun secara penguasan yang lebih terhadap literasi digital pada kelas usia 15-35 Tahun, namun fakta menunjukkan bahwa pada kelas usia tersebut cenderung untuk lebih tidak teredukasi dengan baik dan cenderung untuk abai dalam perilaku keuangannya sehingga mengakibatkan munculnya kesalahankesalahan dalam pengambilan keputusan keuangannya. Fakta ini tentunya tidak terlalu mengejutkan bagi para pengamat perilaku keuangan (Financial Behaviour) dimana pada rentang usia tersebut akan cenderung untuk lebih mengambil resiko atas keputusan investasi dan pembiayaan (Risk Taker) dengan tujuan untuk dapat mengambil keuntungan yang lebih tinggi (High Risk and High Return).

Pemetaan terhadap tingkat literasi keuangan pada masyarakat dunia juga dapat dilihat pada Gambar berikut untuk dapat melihat bagaimana posisi Indonesia pada Tahun 2014 dalam hal penguasaan terhadap literasi keuangan yang dilakukan survei oleh (Lusardi \& Mitchell, 2014), seperti yang diilustrasikan pada Gambar 2 sebagai berikut:

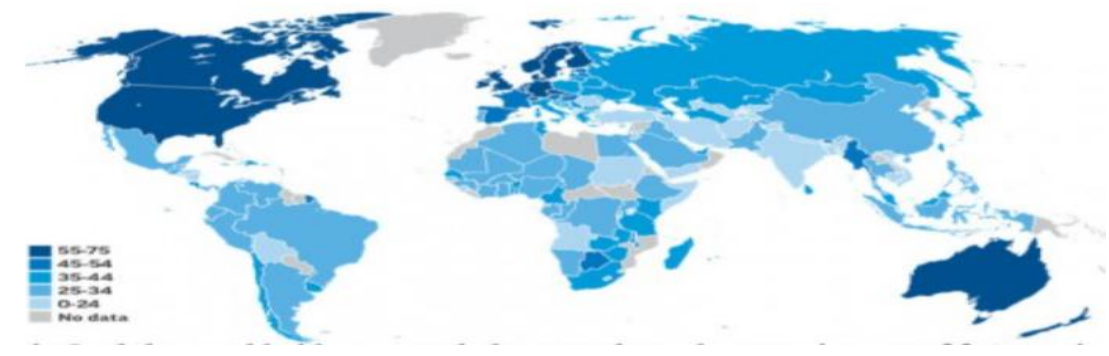

Gambar 2. Ilustrasi Persentase Masyarakat yang Menguasai Literasi Keuangan pada Masyarkat Dunia pada Tahun 2014

Sumber:(Lusardi \& Mitchell, 2014)

Dari Gambar 2 dapat dilihat bahwa tingkat penguasaan literasi keuangan pada masyakat dunia masih belum merata pada Tahun 2014, dimana negara-negara maju telah mengenal institusi keuangan dengan lbih baik, bahkan Negara Australia yang berlokasi tidak jauh dari Indonesia tingkat Penguasaannya sudah diatas 55\% atau sebagaian besar Penduduknya telah mengenal dengan sangat baik bagaimana harus berinvestasi dan memperoleh pembiayaan sehingga dalam prakteknya tentu akan berdampak pada lebih mudahnya penduduk negara tersebut untuk mengakses institusi keuangan tersebut. Indonesia sendiri, dalam penelitian yang dilakukan oleh (OECD, 2020) disebutkan memiliki nilai Financial Literacy sebesar 13.3 dari total nilai 21 atau dapat diartikan bahwa penguasaan sebesar $63 \%$, atau masih diatas nilai rata-rata keseluruhan negara yang dilakukan survey dengan nilai 12.7. Nilai ini juga masih berada diatas negara regional seperti Malaysia (12.5) dan Korea Selatan (13), namun masih berada dibawah Thailand (14) dan Hongkong (14.8), sehingga diperlukan pekerjaan yang lebih luas lagi untuk dapat memperkenalkan institusi keuangan kepada masyarakat melalui literasi keuangan.

Perkembangan pasasr modal di Indonesia sendiri menunjukkan peningkatan jumlah emiten dari 228 Emiten pada akhir tahun 2011 yang dilakukan oleh (Lisnawati \& Budiyanti, 2011), sedangkan pada saat penelitian ini (per tanggal 8 Agustus 2021) jumlah emiten yang terdaftar di papan Bursa Efek Indonesia tercatat sebanyak 740 Emiten.(Indonesia Stock Exchange, 2021) atau mengalami peningkatan lebih dari 200\% dibandingkan tahun 2011. 
Hal ini menggambarkan bahwa Pasar Modal di Indonesia mulai di jadikan alternatif pembiayaan oleh emiten di Indonesia sehingga hal ini menuntut para stakeholder di Pasar Modal untuk dapat meningkatkan pemanfaatan teknologi dan adanya literasi keuangan yang semakin mengarah pada pemanfaatan data digital. Pemanfataan teknologi terutama mengambil peranan yang lebih besar atas meningkatnya pengetahuan masyarakat berusia muda dalam hal Literasi Digital, dimana kepemilikan Komputer maupun Gawai Pintar (Smart Phone) dan aplikasi yang ada mendorong terjadinya aksesibilitas terhadap sejumlah literasi baik secara digital maupun fisik dan adanya konektivitas antara masyarakat dengan industri keuangan yang lebih mudah. Hal ini dibuktikan dengan adanya peningkatan literasi digital pada kaum muda apabila dibandingkan antara data publikasi yang dikeluarkan oleh Otoritas Jasa Keuangan pada Tahun 2013 (Otoritas Jasa Keuangan, 2013) dan 2019 (Otoritas Jasa Keuangan, 2019) yang menunjukkan adanya peningkatan jumlah masyarakat berpengetahuan yang baik dalam hal literasi keuangan dari $21.84 \%$ pada 2013 menjadi $38.03 \%$, dimana terlibatnya $40.25 \%$ masyarakat usia muda dengan rincian $2.45 \%$ pada kelompok usia 15-17 Tahun, 13.53\% kelompok usia 18-25 Tahun dan 26-35 Tahun dengan jumlah 24.26\%. Untuk itu, maka dalam prakteknya berbagai pihak yang berkepentingan, baik dari Dunia Akademisi, Industri Keuangan dan Pemerintah mencoba untuk dapat berkolaborasi sehingga dapat meningkatkan pengetahuan masyarakat dalam hal literasi keuangan baik melalui Sosialisasi dan Pelatihan. Diharapkan dengan adanya Sosialisasi dan Pelatihan tersebut, para peserta mendapatkan sejumlah informasi yang relevan dengan Financial Literasi dan Industri Keuangan sehingga akan memberikan alternatif yang lebih luas bagi peserta secara khusus maupun masyarakat secara umum agar dapat teredukasi dengan lebih baik. Pada masa pandemi Covid-19 saat ini, program pelatihan dan sosialisasi dilakukan secara dalam jaringan (daring/online) dengan memanfaatkan sejumlah apliasi berbasis cloud meeting, yang pada akhirnya memiliki dampak seperti dua sisi mata uang yang saling bertolak belakang, dimana pada satu sisi dampak sosialisasi yang diberikan akan semakin luas dimana para peserta dapat menghadiri pertemuan pembelajaran dari jarak jauh (distance learning) sehingga daya cakup pasar yang semakin luas dan harapan akan bertambahnya pengetahuan dari masyarakat atas literasi keuangan akan semakin meningkat. Sedangkan pada sisi lainnya, tingkat efektifitas dilaksanakannya Distance Learning tersebut memerlukan komitmen yang tinggi dari peserta dan adanya kepemimpinan virtual (e-leadership) yang kuat dari narasumbernya dalam berkomunikasi dan memotivasi peserta sehingga pesan dan informasi yang disampaikan akan diterima dengan baik oleh peserta.

Hasil penelitian yang dilakukan oleh sejumlah peneliti menunjukkan dengan jelas bahwa konsep e-leadership muncul dikarenakan adanya perubahan dalam perusahaan atau organisasi yang diakibatkan juga oleh adanya sebuah revolusi atau disrupsi yang mengarahkan pemanfaatan digital atau komunikasi dengan perangkat elektronik secara lebih luas sehingga para penggunanya harus mampu untuk menguasai, mengatur dan mengkoordinasikan segala sumber daya atau sering juga disebut sebagai “Collaboration Tools" atau Alat berkolaborasi.(Van Wart et al., 2019). Dengan demikian maka peralihan makna kepemimpinan dari orang yang memberikan perintah menjadi bagian dari sistem yang melayani kebutuhan dari organisasi melalui kolaborasi dengan sejumlah pihak merupakan titik temu baru yang digunakan juga untuk memotivasi dan mengkomunikasikan pesan atau informasi yang dimiliki oleh pemberi pesan kepada para komunikan dengan tujuan agar komunikan dapat berperilaku seperti yang diinginkan oleh komunikator. Agar dapat berperilaku seperti yang komunikator inginkan, maka kemampuan penguasan ruang virtual menjadi sangat penting, yang ditunjang oleh sejumlah variabel lainnya yaitu pengetahuan dan ketersediaan jaringan (media) yang memadai sehingga proses komunikasi antara pihak-pihak dapat lebih baik terlaksana (Darics, 2020). Dalam penelitian (Darics, 2020) dengan jelas disebutkan bahwa pengalaman yang dimiliki oleh komunikator sebelum berada para ruang virtual memberikan pengaruh paling besar untuk dapat menyusun strategi penyampaian atau komunikasi yang lebih tepat. Pemilihan alternatif yang dimaksud diantaranya adalah alternatif bahasa yang digunakan dan adanya interaksi sosial yang tidak kaku akan mendorong komunikasi yang disampaikan lebih efektif. Investasi pada surat berharga mulai dikenal oleh masyarakat. Masyarakat mulai mengenal saham dan berbagai bentuk surat berharga lainnya. Pasar modal merupakan pasar yang memfasilitasi perdagangan saham. Saham merupakan salah satu instrument pasar keuangan yang paling populer, dan juga pada saat ini saham juga merupakan salah satu instrument investasi yang banyak diminati oleh para investor negara maju maupun berkembang. Hal ini ditenggarai saham diharapkan mampu memberikan tingkat keuntungan yang menarik dibandingkan instrumen investasi lainnya. Pada saat ini sebagian masyarakat Indonesia sudah mulai mengenal apa itu investasi saham, namun pada kenyataannya kaum milenial masih banyak yang belum akrab dengan investasi. Hal ini terbukti dengan sejumlah laporan yang dikeluarkan oleh Press Release Bursa Efek Indonesia yang mulai menyasar kaum muda di Indonesia untuk berinvestasi semenjak dini, dengan mengaktifkan peran serta Universitas dan Badan Organisasi Kemahasiswaan yaitu Galeri Investasi. Pada tahun 2021 berdasarkan data yang diperoleh dari www.idx.co.id, diperoleh banyak Galeri Investasi yang menjadi mitra Bursa Efek Indonesia telah mencapai 507 unit, yang tersebar di seluruh Indonesia. Fakultas Ekonomi dan Bisnis Universitas Riau sendiri, telah memiliki Badan Galeri Investasi yang pada saat ini diketuai oleh Bapak Drs.Anthony Mayes,M.Si.

Galeri Investasi Universitas Riau sendiri sejatinya merupakan badan yang dimiliki oleh Universitas Riau dan diserahkan pengelolaannya kepada Fakultas Ekonomi dan Bisnis Universitas Riau, telah melakukan sejumlah kegiatan-kegiatan baik yang ditaja secara mandiri, maupun bekerja sama dengan organisasi kemahasiswaan (seperti Himpunan Mahasiswa Jurusan Akuntansi, Manajemen maupun Ilmu Ekonomi), juga menaja kegiatan-kegiatan yang bekerja sama dengan mitra yang berasal dari Perusahaan Sekuritas (Phintraco Sekuritas), dan pihak-pihak terkait lainnya juga menyelenggarakan sosialisasi kepada masyarakat secara luas dengan tujuan untuk dapat meningkatkan 
kesadaran dan literasi keuangan, dan juga dapat menambah keinginan peserta sosialisasi untuk dapat berinvestasi secara langsung ke Pasar Modal. Mahasiswa sebagai generasi yang akan membangun perekenomian di masa depan harus menjadi generasi yang memiliki pengetahuan lebih mengenai investasi terkhususnya investasi saham. Oleh karena itu, diperlukan kegiatan untuk memberikan pengetahuan dasar dan wawasan mengenai investasi saham. Pada kesempatan ini kami segenap panitia mengadakan webinar saha untuk memberikan pengetahuan bagi peserta webinar tentang invesatasi dan keutungannya.

Seperti yang telah diungkapkan diatas, Galeri Investasi telah melakukan kerjasama dan kolaborasi dengan Himpunan Mahasiswa Jurusan Akuntansi Fakultas Ekonomi dan Bisnis Universitas Riau untuk melaksanakan sebuah Webinar Nasional Pasar Modal dengan tema acara "Mendapat Sama Berlaba, Hilang Sama Merugi: Ciptakan Generasi Melek Investasi". Webinar Nasional Saham ini merupakan salah satu program kerja yang bertujuan untuk memberikan gambaran terhadap mahasiswa mengenai investasi saham. Hal ini agar menciptakan generasi yang melek akan investasi di masa depan. Selain itu, Webinar ini diharapakan untuk dapat memberikan dampak berupa tambahan pengetahuan dan wawasan terhadap perkembangan investasi saham yang ada di Indonesia. Adapun dampak tersebut dapat diuraikan sebagai berikut ini:

1. Peserta Webinar diharapkan dapat memahami tentang Investasi Saham

2. Peserta Webinar diharapkan untuk dapat memahami cara trading saham untuk pemula

3. Peserta Webinar diharapkan untuk dapat mengetahui perbedaan antara trader dan investor

4. Peserta Webinar diharapkan untuk dapat mengetahui perkembangan pasar saham di Indonesia

Maka dari itu dalam rangka mengembangkan dan memberdayakan industri kecil dan menengah yang mampu bertahan pada saat kondisi pandemi Covid 19 dan krisis ekonomi serta yang berdaya saing dalam era globalisasi ini, perlu dilakukan pembenahan terhadap industri kecil dan menengah melalui pembuatan penelitian dengan judul "Analisis Dampak Pelaksanaan Webinar terhadap Literasi Keuangan pada Peserta Webinar Nasional Investasi Saham"

1. Bagi Peneliti, dilaksanakannya penelitian ini diharapkan Tim Peneliti dapat menambah wawasan dan meningkatkan pengetahuan Peneliti terkait dengan pelaksanaan Webinar dan peningkatan kompetensi (dimana pada Webinar ini Ketua Peneliti merupakan dipercaya sebagai salah satu Pemateri dan Narasumber)

2. Bagi Pelaksana Webinar, Pelaksanan penelitian ini diharapkan mampu untuk menjadi alat kontrol atas rencana yang telah ditetapkan dengan realisasi di lapangan berdasarkan tanggapan dari Peserta Webinar dan juga memberikan rekomendasi pelaksanaan Webinar pada masa yang akan datang.

3. Bagi Fakultas Ekonomi dan Bisnis Universitas Riau, Fakultas Ekonomi dan Bisnis Universitas Riau (FEB UNRI) sebagai Instansi yang menaungi pelaksanaan Webinar Nasional Saham diharapkan mendapatkan rekomendasi dan juga sebagai alat kontrol atas pelaksanaan Webinar.

\section{METODE PENELITIAN}

\subsection{Teori-Teori Yang Relevan}

Dalam pelaksanaan peneletian, teori yang dijadikan dasar pijakan dalam penelitian ini antara lain:

a. Theory of Planned Behaviour

Teori ini menyebutkan bahwa perlaku positif dan degatif akan sangat mempengaruhi perilaku nyata seseorang, dan diasumsikan bahwa perilaku dapat dilakukan penyesuaian- penyesuaian dengan tujuan untuk dapat memberikan hasil yang lebih baik di masa yang akan datang, dimana pada kasus keuangan kesediaan seorang individu dalam merencanakan masa tuanya dan mempersiapkan dana pensiun sebagai sebuah perilaku yang ditujukan untuk memberikan keamanan masa depan dengan adanya perencanaan masa tua yang lebih baik.

Hubungan Theory of Planned Behaviour dengan Literasi Keuangan dapat dilihat dari sudut pandang penguasaan literasi keuangan yang lebih baik akan dapat diartikan sebagai perubahan atau perencanaan perilaku yang akan berdampak pada alternatif pembiayaan, investasi dan simpanan pada jasa keuangan dengan tujuan untuk kemerdekaan finansial (financial freedom)

b. Symbolic Interaction Theory

Pada symbolic interaction disebutkan bahwa terdapat interaksi berupa simbol yang akan memimpin seorang individu untuk dapat merencanakan karir dan pensiun sehingga dapat memberikan persepsi yang berbeda diantara individu terhadap sebuah permasalahan yang diakibatkan adanya perbedaan penguasaan terhadap sebuah permasalahan. Keterkaitan Symbolic Interaction Theory dengan penelitian ini adalah dengan adanya penguasan terhadap literasi keuangan akan mendorong hadirnya kompetensi dan diiringi oleh adanya motivasi yang tepat dari pemberi pesan atau komunikan (yang dalam hal ini diidentifikasi sebagai e-leadership)

\subsection{Literasi Keuangan}

Literasi Keuangan merupakan sebuah keterampilan yang sangat penting/esensial dan dibutuhkan pada saat ini dalam kehidupan sehari-hari yang disebabkan oleh adanya ketidakpastian atau ketidak stabilan dalam ekonomi global dan munculnya permasalahan-permasalahan yang lebih komplek dikarenakan adanya sejumlah produk-produk keuangan baru yang menawarkan sejumlah kelebihan dan untuk itu maka diperlukan kemampuan untuk dapat mengerti dan 
menganalisa alternatif-alternatif yang diperlukan dalam rangka untuk perencanaan masa depan.(Philippas \& Avdoulas, 2019)

National Centre for Financial Education, menyebutkan bahwa literasi keuangan (Financial Literacy) sebagai sebuah faktor-faktor yang dimiliki oleh seseorang berupa kombinasi atas faktor Keminatan (Awareness),Pengetahuan (Knowledge), Keterampilan (Skil), Sikap (Attitude) dan Perilaku (Behaviour) yang dibutuhkan dengan tujuan untuk dapat menghasilkan sebuah keputusan keuangan dan dapat menjadikan individu tersebut memiliki kemampuan finansial yang baik (well being financial) (National Centre for Financial Education (NCFE), 2019). Literasi Keuangan oleh (Klapper et al., 2019) diterjemahkan sebagai pemahaman dasar atas konsepkonsep yang ada pada manajemen dan institusi keuangan yang akan memberikan kemampuan kepada seseorang atau individu atas alternatif-alternatif pembiayaan, simpanan, investasi dan hal-hal lain yang berhubungan dengan jasa keuangan. Dengan adanya literasi keuangan yang memadai maka akan memberikan kesempatan kepada individu untuk meminimalisir adanya tambahan biaya baik berupa biaya transaksi, atau adanya potensi bunga pinjaman yang lebih besar sehingga dapat lebih kompetitif.

Berdasarkan definisi tersebut, maka dapat diberikan pemaknaan bahwa literasi digital merupakan sebuah kemampuan yang sifatnya wajib dimiliki oleh seorang individu ataupun organisasi untuk lebih kompetitif dengan cara memiliki pengetahuan, sikap ataupun perilaku yang menghadirkan alterntatif yang lebih luas atas jasa keuangan yang tersedia baik dengan tujuan untuk Penyimpanan, Investasi maupun Pembiayaan.

\subsection{E-Leadership}

E-leadership merupakan sebuah paradigma baru dalam kepemimpinan dimana pemimpin dihadapkan pada sebuah kondisi dimana adanya sebuah media baru yaitu ruang digital atau pemanfaatan teknologi dalam melakukan kolaborasi dengan lingkungan dan sumber daya yang ada di dalam sebuah organisasi. (Darics, 2020) e-Leadership merupakan sebuah aspek kepemimpinan yang berkaitan dengan prioritas dan inisiatif dari individu ataupun instansi dalam mengantisipasi dan memanfaatkan kemajuan teknologi informasi sehingga dapat mencapai kemampuan kompetitif di dalam industri. Peranan e-leadership dapat dilihat dengan adanya kemampuan untu menerjemahkan gambaran besar kepada organisasi (visionary), mengelola perbedaan anggota ke arah tujuan yang jelas dan adanya pemecahan masalah (Convener), kemampuan untuk kelompok kerja virtual kepada kelompok kerja nyata (team sponsor) dan mengatur sumber-sumber organisasi dengan penuh tanggung jawab baik pada tataran virtual ataupun nyata (Manager), memiliki kemampuan untuk menemukan cara-cara baru atas pekerjaan dan fungsinya (inovator) dan mengarahkan pemimpin baru di lingkungan organisasinya (Mentor) (Anwaruddin, 2009). Dengan demikian, maka e-leadership dapat diterjemahkan sebagai sebuah kemampuan dari seorang pimpinan untuk dapat menghasilkan sebuah kolaborasi antara pekerjaan di dunia nyata dengan sumber daya organisasi secara virtual dan menghasilkan capaian-capaian yang telah ditetapkan sebelummnya oleh organisasi.

\subsection{Investasi Saham}

Saham sebagai sebuah instrumen pasar modal diberikan definisi oleh sejumlah ahli dalam buku dan tulisan sebagai berikut:

a. (Van Horne \& Wachowicz, 2013) merupakan sebuah bukti kepemilikian kolektif oleh sejumlah pihak dan juga merupakan bagian kepemilikan resiko dari para pemilik atas kegiatan korporasi. Dalam kasus likuiditas, besaran persentase kepemilikan (hasil bagi antara nilai investasi dengan nilai saham yang beredar) akan menentukan nilai residual aset setelah klaim atas hutang dan saham preferen.

b. (Kasper \& Nielsen, 2010) menerjemahkan saham sebagai bukti kepemilikan individu atau organisasi terhadap sebuah entitas bisnis yang terdiri atas saham preferen (prefered stock) dan saham biasa (common stock), yang nilainya merupakan nilai sekarang dari harapan keuntungan berupa peningkatan nilai pasar saham dan dividen dan faktor-faktor resiko yang didapatkan atas hasil investasi.

c. (Ross et al., 2010) memberikan informasi bahwa saham merupakan sebuah instrumen keuangan yang menyatakan kepemilikan dari sebuah organisasi/individu terhadap sebuah perusahaan, dengan hak-hak yang melekat didalamnya beupa Proxy Voting, Deviden, Klaim atas Aset pada saat Likuidasi dan Hak atas Tindakan Strategis Korporasi (serta adanya hak mempertahankan invetasi berupa preemptive right)

Berdasarkan definisi yang telah diungkapkan oleh sejumlah akademisi tersebut, maka dapat dimaknai sebagai bukti kepemilikan kolektif oleh sejumlah individu dan atau organisasi, dengan tujuan untuk mendapatkan potensi kenuntungan berupa Deviden dan Capital Gain, serta mengendalikan resiko atas aksi korporasi di masa yang akan datang berupa likuiditas.

\subsection{Cara Trading Ssaham Untuk Pemula}

Pengetahuan tentang mekanisme dan cara Perdagangan Saham dapat digambarkan seperti pada Gambar berikut ini: 


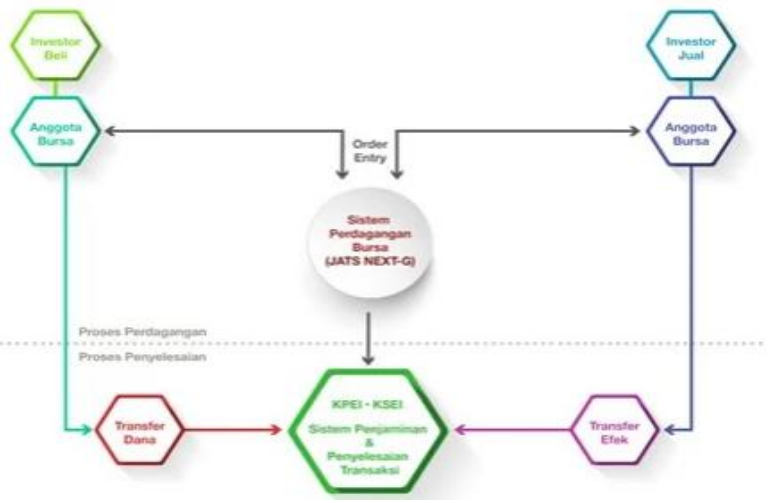

Gambar 3. Alur Perdangan Saham di Bursa Efek Indonesia Sumber: (Indonesia Stock Exchange, 2021)

Pada Gambar 3, dapat dilihat bahwa terdapat sejumlah pihak yang terlibat dalam perdagangan efek, diantaranya adalah sebagai berikut (Indonesia Stock Exchange, 2021):

a. Self Regulatory Organization (SRO)

Berdasarkan Undang-Undang Republik Indonesia No 11 Tahun 2011 tentang Otoritas Jasa Keuangan pada Pasal 4 dalam (Undang-Undang No 21 Tahun 2011 Tentang Otoritas Jasa Keuangan, 2011) disebutkan bahwa dalam melaksanakan fungsi pengawasan terhadap Bursa Efek Indonesia dan sejumlah lembaga keuangan non bank, didirikanlah sebuah lembaga pengawas yang disebut sebagai Otoritas Jasa Keuangan, yaitu lembaga independen dalam melaksakan tugas dan wewenangnya dengan fungsi agar keseluruhan kegiatan dapat terselenggara secara teratur, transparan dan akuntabel serta berkelanjutan dan stabil dan mampu untuk melindungi kepentingan konsumen dan Masyarakat secara terintegrasi pada keseluruhan kegiatan didalam sektor jasa keuangan. Dalam pengaturan dan pengawasan tersebut, Otoritas Jasa Keuangan memiliki wewenang untuk dapat memberikan dan/atau mencabut izin usaha (izin orang perorangan, efektifnya pernyataan pendaftaran, surat tanda terdaftar) pada Lembaga Keuangan dan juga memiliki fungsi untuk melaksakakan fungsi edukasi atau pendidikan terhadap masyarakat sebagai fungsi pencegahan atas resiko.

Khusus pada lembaga keuangan yang berada di sektor Pasar Modal, Otoritas Jasa Keuangan memiliki perpanjangan tangan berupa self regulatory organization (SRO) yaitu lembaga atau organisasi yang melaksakan kewenangan penerapan aturan di industri pasar modal yang terdiri atas Bursa Efek, Kliring Penjamin Emisi, Kustodian Efek Indonesia dan Penyelenggaran Dana Perlindungan Pemodal seperti yang dimuat pada UndangUndang No 8 Tahun 1995 (Undang-Undang Republik Indonesia Nomor 8 Tahun 1995 Tentang Pasar Modal, 1995).

b. Investor Beli

Investor Beli merupakan calon investor atau investor yang telah terdaftar sebelumnya, yang memiliki kelebihan dana untuk diinvestasikan dalam bentuk pembelian efek atau surat berharga yang dikeluarkan oleh emiten terdaftar di bursa efek, dan melakukan potensi beli pada anggota bursa efek.

c. Investor Jual

Investor Jual merupakan investor yang telah terdaftar memiliki efek atau surat berharga dan memiliki kebutuhan untuk mendapatkan dana dari potensi penjualan efek yang dimilikinya melalui perantara anggota bursa efek.

d. Anggota Bursa

Yang dimaksud dengan Anggota Bursa Efek yaitu Lembaga Perantara Pedagang Efek yang memperoleh izin usaha dari Bapepam (Sekarang disebut sebagai Otoritas Jasa Keuangan-OJK) dan mempunyai hak untuk mempergunakan sistem dan atau sarana Bursa Efek sesuai dengan peraturan Bursa Efek.

e. Sistem Perdagangan Bursa Efek Indonesia (JATS-NEXT G)

JATS-Next G merupakan sebuah sistem yang dibangun oleh Bursa Efek dan SRO, dengan tujuan untuk meminimalisir resiko serta mempermudah terjadinya transaksi jual maupun beli di antara anggota bursa. Dengan adanya sistem perdagangan di Bursa Efek Indonesia saat ini, maka proses transaksi dan kepemilikan saham dapat dilakukan dengan paperless (tanpa bukti fisik) dan juga lebih terjamin dikarenakan adanya digitalisasi data yang terintegrasi dalam satu sistem.

Dalam prakteknya, pelaksanaan perdagangan di Bursa Efek Indonesia mengikuti sejumlah kaidah diantaranya adalah sebagai berikut ini:

a. Segmentasi dan Penyelesaian Transaksi

Dalam prakteknya, pelaksanaan transaksi di Bursa Efek dapat dibagi atas 3 jenis yaitu Pasar Reguler, Pasar Tunai, dan Pasar Negoisasi yang terminologinya dapat diuraikan sebagai berikut:

i. Pasar Reguler dan Pasar Tunai

Pasar Reguler merupakan segmentasi Pasar yang waktu penyelesaiannya pada Hari Bursa ke-2 setelah terjadinya Transaksi Bursa $(\mathrm{T}+2)$, sedangkan Pasar Tunai merupakan segmentasi pasar yang waktu 
penyelesaiannya Hari Bursa yang sama dengan terjadinya Transaksi Bursa (T+0). Dengan demikian, maka pada kedua jenis tersebut mengikuti kaidah-kaidah sebagai berikut ini

Penawaran jual dan atau permintaan beli yang telah dimasukkan ke dalam JATS NEXT-G diproses oleh JATS NEXT-G dengan memperhatikan prioritas harga dan waktu (price and time priority)

ii. Pasar Negoisasi

Perdagangan Efek di Pasar Negosiasi dilakukan melalui proses tawar menawar secara individual (negosiasi secara langsung) antara:

- Anggota Bursa atau

- Nasabah melalui satu Anggota Bursa atau

- Nasabah dengan Anggota Bursa

Dengan telah diketahuinya mekanisme perdagangan dan waktu penyelesaian dari pasar reguler, tunai dan negoisasi, maka investor juga diharapkan memiliki pengetahuan tentang biaya yang muncul pada setiap jenis pasar, yang berasal dari SRO sebagai berikut ini

\begin{tabular}{|l|c|c|c|}
\hline & Pasar Reguler & Pasar Tunai & Pasar Negoisasi \\
\hline Biaya Transaksi BEI & $0,018 \%$ & $0,018 \%$ & $0,018 \%$ \\
\hline Biaya Kliring KPEI & $0,009 \%$ & $0,009 \%$ & $0,009 \%$ \\
\hline Biaya Penyelesaian KSEI & $0,003 \%$ & $0,003 \%$ & $0,003 \%$ \\
\hline Dana Jaminan KPEI & $0,010 \%$ & $0,010 \%$ & - \\
\hline PPN 10\% & $0,003 \%$ & $0,003 \%$ & $0,003 \%$ \\
\hline $\begin{array}{l}\text { PPh Final 0,1\%* } \\
\text { (Hanya Transaksi Jual) }\end{array}$ & $0,100 \%$ & $0,100 \%$ & $0,100 \%$ \\
\hline \multicolumn{1}{|c|}{ Total } & $\begin{array}{l}0,143 \% \text { (Jual) } \\
0,043 \% \text { (Beli) }\end{array}$ & $\begin{array}{l}0,143 \% \text { (Jual) } \\
0,043 \% \text { (Beli) }\end{array}$ & $\begin{array}{l}0,133 \% \text { (Jual) } \\
0,033 \% \text { (Beli) }\end{array}$ \\
\hline
\end{tabular}

Gambar 4. Biaya Yang Timbul pada Masing-Masing Pasar di Bursa Efek Indonesia Sumber: (Riawan et al., 2019)

b. Jenis-Jenis Efek yang diperdagangkan dan tata caranya.

Pada Bursa Efek Indonesia terdapat sejumlah efek atau surat berharga yang diperdagangkan selain saham, diantaranya adalah obligasi dan sukuk (obligasi syariah), Perdagangan Derivatif, yang mekanisme perdagangannya diuraikan sebagai berikut:

i. Obligasi dan Sukuk

Fixed Income Trading System (FITS) adalah sarana perdagangan obligasi dan sukuk (obligasi Syariah) yang disediakan oleh Bursa Efek. Dengan mekanisme melalui sistem FITS transaksi yang dilakukan terintergrasi antara sistem perdagangan, kliring dan penyelesaian, melalui dua papan perdagangan yaitu Pasar Regular Outright dan Pasar Negoisasi.

Biaya yang muncul atas Perdagangan melalui sistem FITS pada dasarnya terbagi atas 3 kelompok besar dengan nilai nominal lebih kecil dari 500 Juta Rupiah (dengan dana jaminan Rp.20.000 dan biaya sebesar Rp.35.000), 500 Juta sampai 10 Milyar Rupiah (dengan dana jaminan 0.005\% dan biaya transaksi sebesar $0.0075 \%$ ), serta Transaksi diatas 10 Milyar Rupiah (dengan jaminan 3.75 permil dan biaya transaksi sebesar $0.005 \%$ ) dan seluruh transaksi dikenakan pajak PPN Final $10 \%$.

ii. Derivatif

Perdagangan Produk Derivatif dilakukan dengan menggunakan Jakarta Automated Trading System (JATS). Pengguna sistem JATS adalah Perusahaan Efek yang sudah menjadi Anggota Bursa. Penawaran jual dan/atau permintaan beli produk derivatif hanya dapat dilakukan melalui Anggota Bursa Derivatif. Produk Derivatif yang diperdagangkan di Bursa Efek Indonesia saat ini ada 2 (dua), yaitu Kontrak Berjangka Indeks Efek (KBIE) LQ-45 dan KBSUN atau indeks derivatif lainnya. Pada perdagangan derivative, Anggota Bursa Efek bertanggung jawab atas seluruh transaksi yang dilakukan di Bursa baik untuk kepentingan sendiri maupun untuk kepentingan nasabah.

Perdagangan Derivatif diselenggarakan melalui JATS berdasarkan proses tawar-menawar secara lelang berkesinambungan (continuous auction). Penawaran jual dan/atau permintaan beli produk derivatif yang diterima oleh JATS diproses oleh JATS dengan memperhatikan prioritas harga (price priority).. Contoh Produk Derivatif yang diperdagangkan di Bursa Efek Indonesia antara lain Indeks LQ-45, Kontrak Berjangka SUN, IDX 30 Future dan Kontrak Berjangka Sekumpulan SUN dengan periode kontrak yang beragam dan dengan biaya transaksi seperti yang telah ditetapkan oleh Bursa.

\subsection{Perbedaan Antara Trader dan Investor}

Dalam buku edukasi yang diterbitkan oleh (Sekuritas, 2015) disebutkan bahwa sebutan untuk investor merujuk pada orang yang melakukan strategi jual dan atau beli saham dalam jangka panjang dan lebih mengandalkan pada prospek yang diindikasikan pada analisa fundamental dan tidak terlalu dipusingkan dengan fluktuasi atau perubahan harga yang terjadi di pasar saham. Sedangkan terminologi trader merujuk pada orang-orang atau organisasi yang melakukan aktivitas jual beli saham dalam jangka waktu yang lebih pendek dan memanfaatkan momentum 
pergerakan nilai saham untuk mengambil keuntungan melalui indikasi-indikasi pada analisa teknikal. Perbedaan mendasar yang dapat dilihat dari terminologi Trader dan Investor dapat dilihat pada tabel berikut ini:

\begin{tabular}{|l|c|c|}
\cline { 2 - 3 } \multicolumn{1}{c}{} & Trader & \multicolumn{1}{c}{ Investor } \\
\hline Strategi & Buy dan Sell & Buy dan Hold \\
\hline Pengambilan Keputusan & Analisa Fundamental & Analisa Teknikal \\
\hline Fokus & Kinerja Perusahaan & Momentum kenaikan Harga \\
\hline Jangka Waktu & Harian-maskimal 1 bulan & > tahun \\
\hline
\end{tabular}

Gambar 1. Perbedaan Trader dan Investor Sumber: (Sekuritas, 2015)

Selain hal-hal yang telah diungkapkan tersebut, penelitian ini juga merujuk pada sejumlah penelitian yang dilakukan oleh ahli dan akademisi lain yang dapat dilihat pada tabel berikut

Tabel 1. Penelitian Terdahulu

\begin{tabular}{ccl}
\hline No & Nama Peneliti & \multicolumn{1}{c}{$\begin{array}{c}\text { Variabel yang } \\
\text { Diteliti }\end{array}$} \\
\hline 1 & (Lusardi \& & Financial Literacy \\
& Mitchell, 2017) & \\
& & \\
& & \\
& & \\
& & \\
2 & (Philippas \& & \\
& Avdoulas, 2019) & Financial Literacy \\
& & Financial Well- \\
& & Being \\
& & Gen Z Behaviour
\end{tabular}

Literasi Keuangan akan sangat bermanfaat dalam terciptanya sebuah generasi dan bangsa yang dapat berfungsi dengan baik, dimana masyarakatnya telah mengerti dan memahami semenjak dini terkait dengan pilihan-pilihan keuangan yang akan diambil dan adanya perencanaan keuangan yang dilakukan dengan matang berupa adanya diversifikasi investasi dan pembiayaan sehingga dapat terciptanya financial freedom.

Pada penelitian ini juga disebutkan bahwa peran penting hadirnya educator atau pendidik yang mampu untuk mengkolaborasikan sumber daya yang ada pada pekerja sehingga pada masa tuanya akan dapat menghasilkan aset yang dapat membiayai dengan benar. Dan dalam hal itu maka kuatnya kepemimpinan educator tersebut dirasakan sangat berperan penting, untuk dapat mentransfer pengetahuan keuangannya kepada komunikannya

Keampuan literasi dan adanya keraguan dalam menentukan keputusan keuangan memberikan peran penting bagi generasi $\mathrm{Z}$ dalam memutuskan keputusan penting dalam merencakan masa depan atau pensiunnya. Peran serta dari teknologi yang ada saat ini mampu untuk merubah perilaku dari mahasiswa yang ada pada Generasi Z, walaupun masih terdapt beberapa kondisi yang mengakibatkan seorang mahasiswa belum mampu memutuskan alternatif keuangan yang harus dipilih. Dalam kasus di Negara Yunansi, peranan perencana keuangan yang memiliki massa atau pengikut yang besar akan menjadikan seseorang beralih pada sebuah program keuangan.

3 (Yi et al., 2019) Financial Literacy Kemampuan literasi tidak dipengaruhi oleh tingkatan pendidikan Retirement Planning yang dimiliki oleh individu, namun sangat dipengaruhi oleh kemampuan individu dan kesediaan individu untuk mempelajari Education Level

4 (The American Financial Literacy College of Financial Financial Service, Knowledge 2020) komunikasi yang baik.

Hasill survey yang dilakukan menemukan bahwa sebagian besar mahasiswa dengan kemampuan finansial yang cukup akan cenderung untuk mencari alternatif pembiayaan dan investasi sehingga dapat mendorong kebermanfaatan yang lebih besar, namun demikian dikarenakan kurangnya edukator dengan pengetahuan dan kepemimpinan yang tepat berakibat pada kesalahan dalam keputusan investasinya.

4 (Setianingsih et Pendampingan Hasil Workshop menunjukkan bahwa terjadi peningkatan signifikan al., 2021)

Workshop Sistem Trading Saham

5 (Piaw et al., Financial Literacy, 2012) Investment Education terhadap pengetahuan dan minat investasi para peserta.

Hasil penelitian menunjukkan bahwa terjadi peningkatan secara signifikan atas ketertarikan, motivasi, dan kemauan untuk belajar serta adanya perubahan perilaku dalam pembelajaran trading saham pada para pelajar yang menjadi peserta investment education. 


\subsection{Lokasi dan Waktu Penelitian}

Lokasi penelitian adalah Kota Pekanbaru, dengan waktu penelitian dilakukan selama 5 bulan yang akan berlangsung berlangsung pada bulan Juli hingga November 2021.

\subsection{Populasi dan Sampel}

Populasi dalam penelitian ini adalah seluruh peserta webinar nasional saham yang dilaksanakan oleh Fakultas Ekonomi dan Bisnis Universitas Riau yang dalam prakteknya dioperasionalkan oleh Himpunan Mahasiswa Akuntansi Fakultas Ekonomi dan Bisnis Universitas Riau. Pelaksanaan Webinar Nasional Saham dengan Tema "Mendapat Sama Berlaba, Hilang Sama Merugi: Ciptakan Generasi Melek Investasi." yang dilakukan secara daring pada hari Senin, 26 Juli 2021 dengan peserta yang berasal dari sejumlah kampus di Indonesia dengan jumlah 340 Orang yang ditetapkan sebagai populasi penelitian. Pemilihan sampel pada penelitian ini menggunakan teknik convinience sampling, yaitu responden penelitian yang menjadi sampel penelitian adalah bagian dari populasi yang bersedia memberikan tanggapan terhadap instrumen penelitian yang diedarkan (Greener, 2008). Sedangkan sample size atau ukuran sampel ditentukan dengan menggunakan tabel bantu yang di:ciptakan oleh King seperti yang dikutip dalam (Soegiyono, 2007) dengan tingkat kesalahan $(\alpha)=10 \%$ dan N=340 Orang, diperoleh ukuran sampel sebesar 151 (seratus lima puluh satu) orang.

Tabel 2. Operasionalisasi Variabel Penelitian

\begin{tabular}{|c|c|c|c|}
\hline No & Variabel & Dimensi/Indikator & $\begin{array}{c}\text { Skala } \\
\text { Pengukuran }\end{array}$ \\
\hline \multirow{2}{*}{1} & \multirow{2}{*}{ Pemahaman terhadap Investasi Saham } & Definisi Saham & Nominal \\
\hline & & Jenis-jenis Saham & Nominal \\
\hline \multirow[b]{2}{*}{2} & \multirow{2}{*}{$\begin{array}{l}\text { Pemahaman terhadap Mekanisme Trading Saham } \\
\text { Bagi Pemula }\end{array}$} & Jenis-Jenis Pasar di Pasar Modal & Nominal \\
\hline & & $\begin{array}{l}\text { Lembaga yang terlibat pada Trading } \\
\text { Saham }\end{array}$ & Nominal \\
\hline 3 & Pemahaman Perbedaan Trader dan Investor & $\begin{array}{l}\text { Perbedaan Investor dan Trader dari } \\
\text { Definisi }\end{array}$ & Nominal \\
\hline 4 & $\begin{array}{l}\text { Pemahaman Perkembangan Pasar Saham di } \\
\text { Indonesia }\end{array}$ & $\begin{array}{l}\text { Jumlah Emiten Terdaftar } \\
\text { Badan Pengawas Pasar Modal }\end{array}$ & $\begin{array}{l}\text { Nominal } \\
\text { Nominal }\end{array}$ \\
\hline
\end{tabular}

\subsection{Teknik Pengumpulan Data}

Data yang diperlukan dalam penelitian ini ialah data primer dan data sekunder yang terkait dengan menggunakan instrumen penelitian berupa kuesioner penelitian untuk mendapatkan data primer. Data sekunder yang diperlukan dalam penelitian ini adalah data yang telah diolah lebih lanjut dan disajikan baik oleh Panitia Penyelenggara Webinar berupa Data Peserta yang berisikan Informasi Peserta Webinar berupa Nomor Whatsapp, Email aktif yang akan digunakan untuk dapat menghubungi peserta.

\subsection{Metode Analisis Data}

Pada penelitian ini, data yang telah dikumpulkan dan direkapitulasi, akan dilakukan analisa menggunakan pendekatan statistik deskriptif, dengan cara sebagai berikut:

i. Menghitung Jumlah Responden yang memberikan Jawaban yang benar sebelum dilakukan Webinar.

ii. Menghitung Jumlah Responden yang memberikan Jawaban yang benar setelah dilakukan webinar

iii. Merekapitulasi dampak webinar sebelum dan sesudah webinar dengan menggunakan teknik cross tabulation.

\section{HASIL DAN PEMBAHASAN}

\subsection{Identitas Responden}

Identitas Responden pada penelitian ini terdiri atas Jenis Kelamin, Usia, Asal Responden:

\section{a. Jenis Kelamin Responden}

Dengan menggunakan teknik sampling convinience sampling, diperoleh 151 orang responden sebagai sampel penelitian dengan rincian seperti yang diuraikan pada Gambar 6 berikut ini

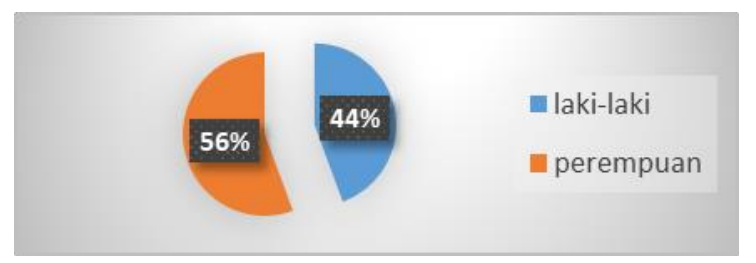

Gambar 4. Rekapitulasi Identitas Responden Berdasarkan Jenis Kelamin 
Berdasarkan data yang ditunjukkan oleh Gambar 6 dapat dilihat bahwa Responden yang memberikan tanggapan atas pertanyaan yang diajukan melalui kuesioner didominasi oleh Responden Wanita, dengan proporsi sebanyak 56\% dari total responden. Hasil ini secara tidak langsung dapat menggambarkan kondisi yang ada pada Populasi, dimana 70\% dari total Peserta Webinar merupakan Peserta berjenis kelamin wanita.

\section{b. Usia Responden}

Untuk dapat menggambarkan usia responden, dapat dilihat pada gambar 7 berikut ini:

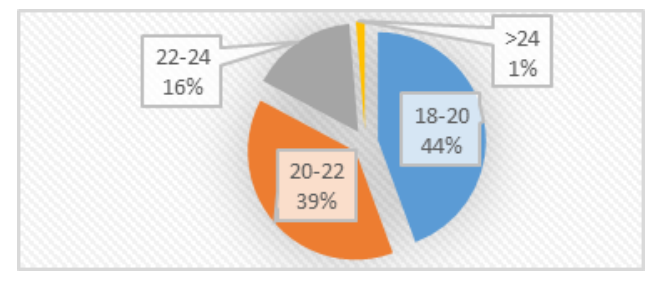

Gambar 5. Rekapitulasi Identitas Responden berdasarkan Usia

Informasi yang diperoleh pada Gambar 7, menunjukkan bahwa pada setiap cluster atau kelompok usia telah dapat digambarkan dengan jelas, dimana data yang diperoleh juga selaras dengan proporsi yang terjadi pada populasi penelitian, dimana proporsi terbesar pada populasi sama dengan kelompok usia pada sampel yaitu pada kelompok usia 18-20 Tahun. Sedangkan kelompok dengan jumlah paling kecil juga sama yaitu pada kelompok diatas usia 24 Tahun. Dengan demikian, maka berdasarkan dua indikator awal ini, maka diasumsikan bahwa proporsi sampel penelitian mendekati proporsi yang ada pada Populasi Penelitian.

\section{c. Asal Responden}

Gambaran proporsi sampel penelitian berdasarkan asal responden, yang dibagi dalam 3 kelompok besar yaitu "Peserta yang berasal dari FEB UNRI", "Peserta yang berasal dari UNRI non FEB", serta "Peserta yang berasal dari luar UNRI" yang dapat digambarkan sebagai berikut:

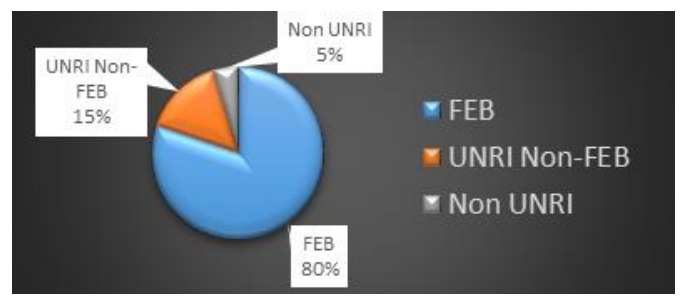

Gambar 6. Rekapitulasi Identitas Responden Berdasarkan Asal Peserta Webinar

Berdasarkan informasi yang ditunjukkan pada Gambar 8, dapat dilihat bahwa secara keseluruhan telah memiliki keterwakilan, dimana sebahagian besar peserta webinar berasal dari Fakultas Ekonomi dan Bisnis Universitas Riau, sebagai penyelenggara kegiatan. Sedangkan peserta yang sifatnya dari umum (non FEB UNRI) juga telah terekam dalam penelitian ini yang dibuktikan dengan 20\% dari total sampel dari luar FEB UNRI telah didapatkan tanggapannya.

\subsection{Rekapitulasi Perbandingan Jawaban Responden Sebelum dan Sesudah Webinar Dilakukan.}

1. Rekapitulasi Perubahan Tanggapan Responden untuk mengetahui Pemahaman terhadap Investasi Saham

Tabel 3. Rekapitulasi Perubahan Tanggapan Responden untuk mengetahui Pemahaman Definisi Saham Sebagai Dampak Pelaksanaan Webinar

\begin{tabular}{cccc}
\hline & \multicolumn{2}{c}{ Sesudah Webinar } & \\
\cline { 2 - 3 } Sebelum Webinar & Benar & Salah & Grand Total \\
\hline Benar & 72 & 39 & 72 \\
Salah & 40 & 39 & 79 \\
Grand Total & 112 & 151 \\
\hline
\end{tabular}

Tabel 4. Rekapitulasi Perubahan Tanggapan Responden untuk mengetahui Pemahaman Jenis-Jenis Saham Sebagai Dampak Pelaksanaan Webinar

\begin{tabular}{cccc}
\hline & \multicolumn{2}{c}{ Sesudah Webinar } & \\
\cline { 2 - 3 } Sebelum Webinar & Benar & Salah & Grand Total \\
\hline Benar & 66 & & 66 \\
Salah & 43 & 42 & 85 \\
Grand Total & 109 & 42 & 151 \\
\hline
\end{tabular}


Investasi dalam fungsi pendapatan diilustrasikan sebagai sisa atau hasil yang disisihkan setelah fungsi konsumsi dan simpanan (saving), sehingga dapat diartikan bahwa perilaku investasi akan muncul dari sebuah entitas bisnis baik individual ataupun organisasi setelah melakukan konsumsi atau produksi dan adanya kelebihan hasil usaha. Oleh (Levišauskaite, 2010) fungsi investasi diberikan rangkuman sebagai sebuah upaya yang dilakukan oleh entitas untuk dapat meningkatkan kekayaan melalui sejumlah pengorbanan atas asset yang dimiliki baik secara langsung atau sering disebut sebagai real investment, maupun investasi atas sejumlah asset financial atau sering disebut sebagai financial investment. Real Investment yang dilakukan, baik oleh individual maupun entitas bisnis berupa perusahaan sering sekali menjadi prioritas atau bahkan menjadi perilaku utama dalam investasi, dimana Uang atau Modal yang dimiliki diinvestasikan dalam bentuk pembelian atau pembiayaan atas asset berupa aset berwujud seperti tanah, bangunan ataupun pabrik serta peralatan dan mesin-mesin produksi dengan tujuan akan menjadi bantuan produksi yang akan menghasilkan imbal hasil setelah periode waktu tertentu. Namun demikian, pada beberapa dekade terakhir investasi dalam bentuk penyertaan modal pada entitas bisnis lainnya juga menjadi alternatif pembiayaan yang mulai diperkenalkan dalam bentuk Financial Investment. Pada pendekatan ini, investasi dilakukan dalam bentuk pembelian saham, ataupun pembiayaan atas entitas bisnis lain melalui pembelian surat hutang (bonds).

Financial Investment seperti yang telah diungkapkan bahwa investasi yang dilakukan tidak secara langsung dilakukan dengan pembelian asset berwujud, tetapi melalui penyertaan modal melalui entitas bisnis lainnya menuntut adanya pemahaman atau pengenalan yang cukup terhadap Perusahaan yang akan diinvestasikan, dan juga jenis investasi yang akan dilakukan terhadap Perusahaan tersebut, apakah penyertaan modal dalam bentuk saham ataupun surat hutang. Dengan semakin banyaknya informasi yang dimiliki oleh calon investor terhadap Perusahaan dan Jenis INvestasi yang akan dilakukan, maka diharapkan Investor dapat lebih tertarik untuk berinvestasi selain juga dapat meminimalisir resiko yang akan dihadapi di masa yang akan datang.

Hasil penelitian yang ditunjukkan pada Tabel 7 menunjukkan bahwa terjadi peningkatan secara signifikan dalam hal pemahaman yang berhubungan dengan "Definisi Saham" dimana sebelum Webinar dilaksanakan lebih dari 50\% dari Peserta Webinar belum dapat mengindetifikasi pernyataan yang benar terkait dengan definisi saham. Pemahaman yang belum tepat tersebut tentunya menjadi indikasi atas kurangnya literasi keuangan yang dimiliki oleh Peserta Webinar. Setelah diselidiki lebih lanjut, pemahaman yang kurang tersebut dapat ditemukan pada Peserta Webinar yang berasal dari Fakultas Ekonomi dan Bisnis Universitas Riau, yang memiliki kajian yang lebih lengkap dibandingkan Peserta yang berasal dari luar FEB UNRI. Dengan demikian maka kehadiran Peserta Webinar sudah sangat tepat, dan dapat mengindikasikan adanya keingin tahuan dari Peserta Webinar terkait dengan pemahaman Saham sebagai Alternatif Investasi di Pasar Keuangan, sebagai bagian dari Literasi Keuangan. Fakta lain yang dapat dilihat pada Tabel 3, juga menunjukkan bahwa sebahagian besar dari Peserta yang diindikasikan kurang memahami "Definisi Saham" pada Pertanyaan 1 kemudian merubah jawabannya sesuai dengan "Definisi Saham" yang tepat sebanyak 40 Orang dari total 79 Orang. Hasil ini mengindikasikan bahwa pelaksanaan webinar menunjukkan peranan yang besar dalam peningkatan kemampuan Mahasiswa. Namun demikian, capaian tersebut masih dirasa perlu untuk ditingkatkan oleh Panitia dan Mitra Kerjanya (dalam hal ini adalah Galeri Investasi Universitas Riau) agar Peserta Webinar yang belum memiliki pemahaman yang tepat kemudian diberikan seri lanjutan yang berkaitan dengan Saham dan Pasar Modal, sehingga dapat lebih mengenal Pasar Modal sebagai alternatif pembiayaan dan investasi.

Sedangkan pada Kemampuan Mengidentifikasi Jenis-Jenis Saham, Hasil Penelitian menunjukkan bahwa sebelum dilaksanakannya Webinar Saham tersebut, masih sebahagian kecil Peserta Webinar berdasarkan data pada Tabel 8 yang dapat mengidentifikasi Jenis-Jenis Saham secara tepat, yang diindikasikan dengan jumlah 85 Orang dari Total 151 Peserta (56.29\%). Dengan adanya temuan tersebut, maka dapat diindikasikan bahwa definisi saham yang telah ditanyakan pada Pertanyaan 1 tidak secara langsung dapat mengindikasikan pemahaman yang lengkap dari Peserta terkait dengan Saham. Dengan telah dilaksanakannya Webinar Saham, dapat dilihat bahwa terjadi pengurangan secara signifikan jumlah Peserta Webinar yang salah dalam mengidentifikasi jenis-jenis saham, dan hal tersebut juga mengindikasikan keberhasilan pelaksanaan dari Webinar Nasional ini.

Sehingga dapat mendorong peserta untuk lebih memahami Saham dan Jenis-Jenisnya, dan memperkuat literasi keuangan Peserta Webinar. Secara keseluruhan dapat dilihat bahwa setelah pelaksanaan webinar terdapat 109 orang Peserta webinar telah mampu memahami jenis-jenis saham atau dapat dikatakan bahwa $72 \%$ dari total Responden berhasil mendapatkan ilmu yang berharga dari Pelaksanaan Webinar. Namun demikian, masih terdapat $28 \%$ Responden yang perlu diberikan perhatian lebih lanjut, sehingga capaian dari Panitia menjadi sempurna dan berdampak lebih besar. Fakta ini secara tidak langsung dapat mengkonfirmasi teori e-leadership dimana narasumber dihadirkan oleh Panitia Webinar mampu untuk memimpin kegiatan yang dilakukan secara virtual, dan juga mampu untuk melakukan transfer pengetahuan kepada Peserta Webinar, yang ditunjukkan dengan adanya peningkatan pengetahuan dari Peserta, baik untuk mengidentifikasi Saham hingga mampu untuk mengidentifikasi jenis-jenis sekuritas yang ada di Pasar Modal. Pengetahuan ini diharapkan akan sangat berpengaruh terhadap perubahan perilaku investasi dari calon investor dalam pemilihan sekuritas yang akan ditanamkan uang atau modalnya. Dengan pemilihan sekuritas yang tepat, maka tingkat resiko dan imbal hasil akan sesuai dengan profil dari calon investor tersebut.

2. Rekapitulasi Perubahan Tanggapan Responden tentang Pemahaman terhadap Mekanisme Trading Saham Bagi Pemula 
Tabel 5. Rekapitulasi Perubahan Tanggapan Responden untuk mengetahui Pemahaman Jenis-Jenis Pasar di Pasar Modal Sebagai Dampak Pelaksanaan Webinar

\begin{tabular}{cccc}
\hline & \multicolumn{2}{c}{ Sesudah Webinar } & \\
\cline { 2 - 3 } Sebelum Webinar & Benar & Salah & Grand Total \\
\hline Benar & 74 & 39 & 74 \\
Salah & 38 & 39 & 77 \\
Grand Total & 112 & 39 & 151 \\
\hline
\end{tabular}

Tabel 6. Rekapitulasi Perubahan Tanggapan Responden untuk mengetahui Pemahaman Peserta terkait dengan Lembaga yang terlibat pada Trading Saham Sebagai Dampak Pelaksanaan Webinar

\begin{tabular}{cccc}
\hline & \multicolumn{2}{c}{ Sesudah Webinar } & \\
\cline { 2 - 3 } Sebelum Webinar & Benar & Salah & Grand Total \\
\hline Benar & 72 & & 72 \\
Salah & 37 & 42 & 79 \\
Grand Total & 109 & 42 & 151 \\
\hline
\end{tabular}

Pemahaman terhadap cara trading saham di Pasar Modal terutama bagi Investor Pemula memainkan peran penting setelah adanya pemahaman terhadap instrument investasi yang tersedia di Pasar Modal dan profil resiko masing-masing instrument tersebut. Hal ini dinyatakan secara jelas oleh (Riawan et al., 2019) yang menyatakan setelah pelaksanaan pelatihan trading yang mengundang masyarakat, membantu masyarakat untuk lebih mengerti mekanisme trading saham yang dimulai dari pemilihan perusahaan sekuritas yang tepat dan terpercaya, dan juga mampu untuk meningkatkan kepercayaan dari Investor terhadap mitigasi resiko yang dimiliki oleh sistem pada Bursa Efek Indonesia. Pernyataan ini juga didukung oleh hasil pengabdian yang dilakukan oleh (Piaw et al., 2012; Setianingsih et al., 2021). Hasil yang diinformasikan oleh Tabel 9 dapat menggambarkan bahwa sebelum dilaksanakanya Webinar Saham, Peserta yang belum memahami Mekanisme Perdagangan di Pasasr Modal, yang diindikasikan dengan pilihan jawaban yang tidak sesuai pada kuesioner penelitian. Sebanyak $51 \%$ dari total responden mengindikasikan informasi tersebut atau sebanyak 77 Orang Peserta. Namun demikian dengan pemahaman yang diberikan oleh Panitia Webinar melalui Topik yang disajikan oleh Narasumber yang diundang, $50 \%$ dari Peserta yang memberikan jawaban yang salah tersebut pada akhirnya dapat mengindentifikasi pernyataan yang benar, sedangkan 50\% lainnya masih memilih jawaban yang salah. Hasil ini secara parsial dapat mengidentifikasikan bahwa Narasumber Webinar mampu melakukan transfer of knowledge kepada Peserta Webinar, namun pada sebagian kecil Peserta Masih mengalami kendala untuk menyerap pengetahuan yang diberikan, sehingga diperlukan pemahaman yang lebih baik lagi dari Panitia dan Mitra Kerja Panitia untuk menyelenggarakan Webinar dengan persiapan-persiapan yang lebih matang berupa materi yang disajikan sebelum dilakukannya Webinar.

Hasil pada Tabel 10 mengindikasikan bahwa sebelum dilaksakaknnya Webinar Saham, sebahagian besar Responden belum memahami atau mengidentifikasi Lembaga-lembaga yang terlibat dalam Mekanisme Perdagangan Saham di Bursa Efek Indonesia, yang ditunjukkan melalui jawaban yang salah sebanyak 52\% dari total responden. Hal ini tentunya menjadi pekerjaan rumah bagi Panitia sebelum dilaksanakannya Webinar Saham. Setelah pelaksanaan Webinar Saham, hasil penelitian menunjukkan bahwa terdapat peningkatan pemahaman yang dimiliki oleh Peserta dimana terjadi peningkatan jumlah responden yang menjawab benar pada kuesioner penelitian. Peningkatan tersebut dalam penelitian ini mengindikasikan bahwa dengan telah dilaksanakannya Webinar Saham tersebut, Peserta menjai lebih mengerti Mekanisme Perdagangan Saham di Bursa Efek Indonesia, dan mampu untuk mengidentifikasi pihak-pihak yang terlibat didalamnya. Dengan semakin luasnya pengetahuan dari Peserta Webinar maka diharapkan kejadian-kejadian penipuan atau SCAM yang saat ini menjadi isu yang menghambat calon investor muda untuk masuk dan berinvestasi di Pasar Modal sedikit banyak dapat diatasi. Pemahaman yang lebih baik ini juga akan menjadi penarik bagi Peserta untuk membantu sosialisasi Investasi di Pasar Modal bagi masyarakat yang lebih luas.

\section{Rekapitulasi Perubahan Tanggapan Responden terkait dengan Pemahaman Perbedaan Trader dan Investor}

Tabel 7. Rekapitulasi Perubahan Tanggapan Responden terkait dengan Kemampuan Identifikasi Perbedaan Investor dan Trader dari Definisi Sebagai Dampak Pelaksanaan Webinar

\begin{tabular}{cccc}
\hline & \multicolumn{2}{c}{ Sesudah Webinar } & \\
\cline { 2 - 3 } Sebelum Webinar & Benar & Salah & Grand Total \\
\hline Benar & 94 & & 94 \\
Salah & 33 & 24 & 57 \\
Grand Total & 127 & 24 & 151 \\
\hline
\end{tabular}

Hasil yang diinformasikan pada Tabel 11 menunjukkan hal yang sedikit diluar dugaan dari peneliti, apabila dibandingkan dengan tanggapan responden pada pertanyaan lainnya. Dimana mayoritas jawaban dari responden 
telah mampu mengidentifikasi perbedaan yang jelas antara investor dan trading, yang diidentifikasi dengan jawaban yang tepat oleh 94 orang Responden atau 63\% Peserta. Hasil ini juga menunjukkan bahwa secara implisit sebenarnya responden telah mengenal atau mengetahui terminologi Investor dan Trader dalam praktek, namun penguasan teori yang belum kuat menjadi motivasi dari peserta dalam mengikuti Webinar Saham tersebut.

Dan setelah pelaksanaan webinar, hal tersebut menjadi tambahan bekal bagi responden yang belum dapat mengindentifikasi perbedaan konsep tersebut, yang ditunjukkan dengan adanya pertambahan jumlah responden yang pada akhirnya memiliki jawaban yang tepat, sedangkan sebagian kecil peserta masih belum dapat memahami dengan jelas terminologi dan diksi investor dan trading tersebut. Secara konsep hal ini menunjukkan bahwa masih terdapat Peserta Webinar yang belum siap untuk berinvestasi di Pasar Modal, dan akan cenderung untuk salah dalam pemilihan strategi investasinya di kemudian hari apabila memilih Pasar Modal sebagai alternatif investasi, dan peserta tersebut disarankan untuk mengikuti webinar atau pelatihan lanjutan.

\section{Rekapitulasi Perubahan Tanggapan Responden terkait dengan Pemahaman Perkembangan Pasar Saham di Indonesia}

Tabel 8. Rekapitulasi Perubahan Tanggapan Responden pada Pertanyaan 6 Sebagai Dampak Pelaksanaan Webinar

\begin{tabular}{cccc}
\hline & \multicolumn{2}{c}{ Sesudah Webinar } & \\
\cline { 2 - 3 } Sebelum Webinar & Benar & Salah & Grand Total \\
\hline Benar & 73 & & 73 \\
Salah & 36 & 42 & 78 \\
Grand Total & 109 & 42 & 151 \\
\hline
\end{tabular}

Tabel 9. Rekapitulasi Perubahan Tanggapan Responden pada Pertanyaan 7 Sebagai Dampak Pelaksanaan Webinar

\begin{tabular}{cccc}
\hline & \multicolumn{2}{c}{ Sesudah Webinar } & \\
\cline { 2 - 3 } Sebelum Webinar & Benar & Salah & Grand Total \\
\hline Benar & 69 & 39 & 69 \\
Salah & 43 & 39 & 82 \\
Grand Total & 112 & 151 \\
\hline
\end{tabular}

Informasi yang ditunjukkan pada Tabel 12 menunjukkan bahwa sebahagian besar Peserta belum memiliki pengetahuan yang lengkap terkait dengan jumlah emiten yang terdaftar di Bursa Efek Indonesia, sebagai indikasi atas pengetahuan peserta tentang pilihan-pilihan investasi di Pasar Modal, berupa saham, obligasi atau turunannya yang diemisikan oleh Emiten terdaftar. Dengan kurang lengkapnya pengetahuan tersebut dapat berakibat sempitnya alternatif analisis yang dimiliki oleh Peserta, hingga pada akhirnya di kemudian hari menimbulkan resiko yang lebih besar. Hasil menunjukan bahwa 52\% dari total Responden belum mengenal jumlah emiten sebelum pelaksanan webinar, namun demikian setelah dilaksanakannya webinar 36 peserta dari total 78 orang yang sebelumnya memberikan jawaban yang salah menjadi lebih mengerti dan pada akhirnya menemukan jawaban yang tepat terkait dengan jumlah emiten terdaftar di Bursa Efek Indonesia. Hasil ini menunjukkan peningkatan yang cukup signifikan, dan diharapkan dapat memperkaya pengetahuan banyaknya emiten yang berpotensi untuk dijadikan objek investasi oleh Peserta Webinar dan kemudian dapat diklasifikasikan lebih lanjut berdasarkan potensi resiko dan hasil yang didapatkan.

Pada pertanyaan yang ditujukan untuk menguji pemahaman peserta webinar terkait dengan badan pengawas pasar modal sebagai bentuk jaminan bagi Investor atau calon investor dalam berinvestasi di Pasar Modal. Dengan jawaban yang tepat diberikan oleh Responden akan mengindikasikan bahwa pemahaman yang jelas oleh Peserta Webinar, dimana akan lebih mengenal Otoritas Jasa Keuangan sebagai Lembaga yang ditugaskan sebagai pengganti Badan Pengawas Pasar Modal (BAPPEPAM) pada Undang-Undang no 8 tahun 1995 tentang Pasar Modal. Fungsi Otoritas Jasa Keuangan dan didukung oleh hadirnya Self Regulatory Organization (SRO) di Pasar Modal akan memberikan keamanan dan kenyaman oleh Investor Eksisting maupun calon investor yang akan menanamkan dananya di Pasar Modal. Hasil pada Tabel 13 mengkonfirmasi bahwa masih sedikit responden yang mengenal secara jelas Otoritas Jasa Keuangan, yang ditunjukan dengan 69 Orang atau hanya 45\% dari total Responden. Setelah ditelusuri lebih lanjut, peserta webinar hanya mengenal Otoritas Jasa Keuangan sebagai lembaga yang mengawasi lembaga keuangan seperti bank, leasing, maupun pegadaian.

\section{KESIMPULAN}

Berdasarkan informasi yang telah diberikan maka dapat disimpulkan bahwa Peningkatan pemahaman Peserta Webinar Saham mengalami peningkatan secara nyata yang diindikasikan dengan semakin banyaknya peserta Webinar yang semakin memahami definisi dan jenis-jenis saham. Namun demikian, hasil penelitian juga menunjukkan bahwa masih terdapat sejumlah peserta yang belum memiliki pemahaman yang jelas. Simpulan Penelitian yang menunjukkan masih terdapat sejumlah Peserta Webinar yang belum memiliki pemahaman yang lengkap, memberikan sinyal kepada Panitia dan juga Mitra Kerja (dalam hal ini adalah Galeri Investasi Universitas Riau) untuk kembali mengundang pesertta tersebut dalam webinar yang berkaitan dengan Pasar Modal berikutnya. 
Selain itu ditemukan juga bahwa terjadi Peningkatan Pemahaman Peserta Webinar Saham mengalami peningkatan secara signifikan yang ditandai dengan peningkatan jumlah peserta webinar yang menjawab dengan tepat. Namun demikian, masih terdapat peserta webinar yang belum memiliki pemahaman yang lengkap setelah dilakukannya pelaksanaan Webinar Nasional Saham. Pemahaman yang masih rendah dari Peserta sebelum dilakukannya Webinar Saham dan pada akhirnya memberikan dampak positif pada pemahaman peserta juga dapat menjadi sinyal kepada Galeri Investasi Universitas Riau untuk lebih sering mengadakan Webinar Pasar Modal dengan tema dan Narasumber yang semakin beragam keilmuan dan pengalamannya, sehingga Peserta Webinar (baik yang berasal dari UNRI maupun Umum) mendapatkan pengetahuan yang lebih luas. Peningkatan Pemahaman Peserta Webinar Saham juga mengalami peningkatan secara signifikan dalam hal mengindentifikasi perbedaan investor dan trader, sehingga diharapkan Peserta Webinar dapat menemukan teknik analisa yang tepat berdasarkan strategi investasi (Investasi dan Trading) yang telah dipilih. Namun demikian juga masih ditemukan peserta webinar yang belum memiliki pemahaman yang lengkap setelah dilaksanakannya Webinar Nasional Saham tersebut. Dampak Webinar Pasar Modal tersebut akan semakin nyata terasa apabila dapat disiarkan secara berulang dengan memanfaatkan kanal sosial media yang dimiliki oleh Galeri Investasi ataupun Fakultas Ekonomi dan Bisnis Universtias Riau. Di sisi lain, Peningkatan Pemahaman Peserta Webinar Saham juga berdampak secara nyata terkait dengan kemampuan untuk mengidentifikasi Otoritas Jasa Keuangan sebagai badan yang mengantikan Badan Pengawas Pasar Modal (BAPPEPAM). Simpulan ini juga mengindikasikan bahwa Peserta Webinar telah mengetahui dengan jelas bahwa Investasi di Pasar Modal telah dilindungi oleh sebuah lembaga khusus bernama Otoritas Jasa Keuangan dan sejumlah lembaga yang disebut sebagai SRO (Self Regulatory Organization). Keterbatasan yang dimiliki oleh penelitian ini, yang diungkapkan sebagai panduan bagi peneliti selanjutnya untuk dapat membangun model penelitian yang lebih baik dimana Penelitian ini merupakan penelitian kuantitatif dengan menggunakan pendekatan statistik deskriptif, yang memiliki keterbatasan untuk tidakd dapat melakukan pemotretan atau pencitraan terhadap objek pengamatan yang berbeda. Untuk itu, maka hasil dari penelitian ini hanya menggambarkan kondisi yang ada pada populasi pada waktu dilakukannya penelitian. Keterbatasan lain pada penelitian ini yaitu menggunakan pendekatan sampling menggunakan teknik convinience sampling yang menuntut kerelaan dari Peserta Webinar untuk melakukan pengisian kuesioner, yang secara keilmuan statistika memiliki tingkat akurasi atas keterwakilan pada setiap kelompok menjadi tidak sama. Namun demikian, pada penelitian ini peneliti melakukan mitigasi dengan melakukan penghentian perhitungan apabila jumlah pada kelompok tertentu sudah sangat besar. Pada penelitian ini juga seolah-olah tidak ditemukan Responden yang menjawab secara acak, yang ditandai dengan tidak adanya jawaban salah setelah Kegiatan Webinar dilakukan (post) pada peseta yang sebelumnya menjawab benar (pra), namun demikian hal itu masih mungkin terjadi namun hal tersebut tidak dapat dilakukan pemotretan dikarenakan Tim Peneliti tidak melakukan uji validasi dan realibiitas terhadap item pertanyaan.

\section{UCAPAN TERIMAKASIH}

Penelitian ini merupakan penelitian yang didanai oleh Fakultas Ekonomi dan Bisnis Universitas Riau dengan sumber Dana yang berasal dari PNBP Fakultas Ekonomi dan Bisnis Universitas Riau Tahun Anggaran 2021, sehingga Tim Peneliti mengucapkan terimakasih atas kesempatan yang diberikan kepada Tim.

\section{REFERENCES}

Anwaruddin, A. (2009). E-Leadership: Faktor Kunci Pengembangan Kapasitas Teknologi Informasi dan Komunikasi di Daerah. Jurnal Borneo Administrator, 5(1).

Darics, E. (2020). E-Leadership or "How to Be Boss in Instant Messaging?" The Role of Nonverbal Communication. International Journal of Business Communication, 57(1), 3-29. https://doi.org/10.1177/2329488416685068

Greener, S. (2008). Business Research Methods. In Ventus Publishing. Ventus Publishing. bookboon.com

Undang-Undang Republik Indonesia Nomor 8 Tahun 1995 tentang Pasar Modal, Pub. L. No. 8 Tahun 1995, Lembaran Negara Republik Indonesia (1995). https://doi.org/10.7312/schi13174-003

Undang-Undang No 21 Tahun 2011 tentang Otoritas Jasa Keuangan, Tambahan Lembaran Negara Republik Indonesia 111 (2011). https://www.ojk.go.id/id/regulasi/otoritas-jasa-keuangan/undang-undang/Documents/uu2111_1388664376.pdf

Indonesia Stock Exchange. (2021). IDX.pdf. 2021. www.idx.co.id

Kasper, C., \& Nielsen, M. (2010). Corporate Finance: Part I Download free books at Corporate Finance: Part I Cost of Capital.

Klapper, L., Lusardi, A., Oudheusden, V., Hess, J., \& Ansar, S. (2019). Financial Literacy Around the World: Insight from The Standard \& Poor's Rating Services Global Financial Literacy Survey. Standard \& Poor. http://www.finlit.mhfi.com

Kozak, Y. (2015). International Finance (Training Manual) (5th ed.). Ministry of Education and Science of Ukraine.

Kusrini. (2007). Konsep Dan Aplikasi Pemdukung Keputusan. Andi.

Lisnawati, \& Budiyanti, E. (2011). Perkembangan Pasar Modal Dan Pertumbuhan Ekonomi Di Indonesia: Analisis Vector Autoregressions (VAR). Jurnal Ekonomi Dan Kebijakan Publik, 2(2).

Lusardi, A., \& Mitchell, O. S. (2014). Financial literacy around the world: An overview. https://doi.org/10.1017/S1474747211000448

Lusardi, A., \& Mitchell, O. S. (2017). How Ordinary Consumers Make Complex Economic Decisions : Financial Literacy and Retirement Readiness. 7(3), 1-31. https://doi.org/10.1142/S2010139217500082

National Centre for Financial Education (NCFE). (2019). Financial Literacy and Inclusion in India Final Report. NCFE. 
Ekonomi, Keuangan, Investasi dan Syariah (EKUITAS)

Vol 3, No 2, November 2021, Hal 270-284

ISSN 2685-869X (media online)

DOI 10.47065/ekuitas.v3i2.1092

OECD. (2020). OECD/INFE 2020 International Survey of Adult Financial Literacy. www.oecd.org/financial/education/launchoftheoecdinfeglobalfinancialliteracysurveyreport.htm\%0AThis

Otoritas Jasa Keuangan. (2013). Developing Inndonesian Financial Literacy Index. Otoritas Jasa Keuangan.

Otoritas Jasa Keuangan. (2019). Booklet Survei Nasional Literasi dan Inklusi Keuangan 2019. Otoritas Jasa Keuangan.

Philippas, N. D., \& Avdoulas, C. (2019). Financial literacy and financial well-being among generation-Z university students : Evidence from Greece students: Evidence from Greece. The European Journal of Finance, O(0), 1-22. https://doi.org/10.1080/1351847X.2019.1701512

Piaw, L. L. T., Zawawi, H., \& Bujang, Z. (2012). the Impact of Stock Market Development on Diploma Level Students. International Journal of Education and Pedagogy, 1(3), 11-16. http://myjms.moe.gov.my/index.php/ijeap

Riawan, Kurniasih, R., \& Wahyuningsih, D. W. (2019). WORKSHOP TRADING SAHAM ONLINE DALAM MEMBERIKAN PEMAHAMAN KEPADA MASYARAKAT PONOROGO UNTUK BERINVESTASI DI BURSA EFEK INDONESIA. Jurnal Budimas, 1(1).

Ross, Westerfield, \& Jordan. (2010). Fundamentals of Corp. Finance. In Journal of Chemical Information and Modeling (Vol. 53, Issue 9).

Sekuritas, P. (2015). SERI EDUKASI BEGINNER. In 1 (online). Panin Sekuritas.

Setianingsih, N. A., Asmoro, W. kusumanig, Aalin, E. R., Putranti, E., \& Andari, A. T. (2021). Pendampingan trading saham untuk mahasiswa universitas pawyatan dhaha kediri. Among: Jurnal Pengabdian Masyarakat, 03, 13-18. https://ejournal.umaha.ac.id/index.php/among/article/view/974/852

Soegiyono. (2007). Statistik Untuk Penelitian (E. Mulyatiningsih (ed.)). Penerbit Alfabeta Bandung.

The American College of Financial Service. (2020). The American College of Financial Service Retirement Income Literacy Survey (pp. 1-20). New York Life: Center for Retirement Income.

Van Horne, J., \& Wachowicz, J. (2013). Fundamentals of Financial Management 13th Edition. In Nursing Standard (Vol. 16, Issue 43).

Van Wart, M., Roman, A., Wang, X. H., \& Liu, C. (2019). Operationalizing the definition of e-leadership: identifying the elements of e-leadership. International Review of Administrative Sciences, 85(1), 80-97. https://doi.org/10.1177/0020852316681446

Yi, C. W., Thoong, C. S., Li, L. S., Kit, L. S., \& Hui, Y. T. (2019). Perception Of Youth On The Retirement Planning In Malaysia (Issue August). Faculty of Bussiness and Finance Universiti Tunku Abdul Rahman Press. 